\title{
Influence of the Selected Technological Factors on the Elimination of Misruns
}

Radka Podprocká ${ }^{1}$, Jozef Malik ${ }^{2}$, Dana Bolibruchová ${ }^{1}$

${ }^{1}$ Department of Technological Engineering, Faculty of Mechanical Engineering, University of Zilina, Univerzitna 8215/1, 01026 Žilina. Slovak Republic. E-mail: radka.podprocka@fstroj.uniza.sk.

${ }^{2}$ Metallurgy Faculty, Department of Metallurgy, Iron and Casting, Košice, Slovak Republic. E-mail: jozef.malik@tuke.sk

High pressure die-castin of aluminum alloys is a complicated process depending on a number of factors which relate between each other. That is why these factors must be regulated in the process of casting. This contribution focuses on the possibilities of eliminating the defects of short run. This defect is located on the edge of the flow opening of the casted body STIRNPLATTE 033. From the view of functionality this kind of defect is inadmissible. Experimental castings from the AlSi12CuNiMg alloy were casted by using different technological parameters where the work surface temperature of the mould and the profile layout of the piston path differed. Experimental measurements of the mechanical properties and RTG analysis were conducted. From the measured values it is possible to state that by infringing the optimal temperature in the mould and the incorrect setting of the piston path parameters has the biggest influence on the amount of misruns.

Keywords: cast, misruns, mould, temperature, pressure

\section{Acknowledgement}

This article was created according to grant project VEGA 1/0363/13. Authors are grateful to the grand commission for their assistance.

\section{References}

[1] RAGAN, E. a kol. (2007). Liatie kovov pod tlakom, 392s., FVT Prešov, ISBN 978-80-8073-979-9

[2] VALECKÝ, J. a kol. (1963). Lití kovu pod tlakem, 450 s., SNTL Praha.

[3] LAUKLI, H. I. (2004). High pressure die casting of aluminium and magnesium alloys, Norwegian University of Science and Technology, (Ph.D. thesis).

[4] VINARCIK, E. J. (2003). High Integrity Die Casting Processes, John Wiley and Sons, New York, NY, USA.

[5] NOVÁ, I., NOVÁKOVÁ, I., MACHUTA, J. (2011). Aluminium alloys squeeze casting. In.: Slévárenství. ISSN 1213-2489, Vol. LIX, No. 9-10(2011), p. 304-308.

[6] THIRUGNANAM, M. (2013). Modern high pressure die-casting processes for aluminium casting, Transactions of 61 st Indian Foundry Congress, pp. 1-7

[7] EPERJEŠI, L., MALIK, J., EPERJEŠI, Š., FECKO, D., (2013). Influence of returningmaterial on porosity of diecasting, In: Manufacturing Technology., Vol. 13, No.1, pp. 36-39

[8] BRÜNA, M., KUCHARČÍK, SLÁDEK, A. (2013). Complex evaluation of porosity in A356 aluminium alloy using advanced porosity module, In: Manufacturing Technology, Vol. 13, No. 1, p. 26-30

[9] MICHALCOVÁ, A., VOJTECH, D. (2012). Structure of rapidly sodified aluminium alloys. In: Manufacturing Technology. ISBN 1213-2489. Vol. 11, p. 166-169

[10]PASTIRČÁK, R. (2014). Effect of low pressure application during solidification on microstructure of AlSi alloys. In: Manufacturing Technology. ISSN 1213-2489. Vol. 14, No. 3 (2014), p. 397-402.

[11] TIllová, E., CHAlupová, M., HURTAlOVÁ, L., ĎURNiKOVÁ, E. (2011). Quality control of microstructure in recycled Al-Si cast alloys, In: Manufacturing Technology, Vol. 11, No. 11, p. 70-76 